\title{
Gender Relation Harmony and Carrier Aspiration
}

\author{
A Utaminingsih \\ Universitas Brawijaya Malang \\ Reseacher of Research Center of Media, Literacy and Culture \\ alifiulathin@ub.ac.id
}

\begin{abstract}
This study is conducted in order to analyze gender relations in the family of career women which is done in order to support a successful career in Syariah banking. A model of gender relations is reviewed from theory of gender and feminism, role and role reversal, as well as dual role conflicts which influence motivation and organizational commitment. The subjects have held several managerial positions in Great Malang's Bank Umum Syariah, included nine managers engaged in marital relationship who had worked from 1 to 20 years. The results of this research exhibits that high social support from family, especially from husbands in the form of a harmonious gender relations between husband and wife is able to influence a career woman's success. Based on consideration of certain condition (successful career is great performance in a woman's career and managing the family), therefore in defining successful career women for having an impact on their organizational commitment, they could be categorized into three types are career woman who precedes career over family, career woman prioritizing both career and family in a balanced manner, and career woman who is concerned towards her family rather on career.
\end{abstract}

Keywords: Gender Relations, Career Woman and Career Aspiration

\section{INTRODUCTION}

Social changes that occurred as a result of the feminist movement, as well as emerging studies on the fairer sex, has provided an opportunity for women to take part in public roles. Women who are highly educated and competent in their respective fields could make an appearance in the society that has been traditionally dominated by males (patriarchal).

Career women are very susceptible to dual role conflicts (domestic and public domain), this issue is caused by gender construction. Men are given "privileged position" to be freed from issues related to the domestic activities due to public interest. On the other hand, women are required to serve as a wife, mother and career woman [1].

Women who build their career in the Syariah based banks (Islamic Syariah based banks) as the main resource (ultimate resources). Syariah based banks or Islamic Syariah based banks are considered prominent in Indonesia due to Muslims being majority in Indonesian citizenship. It has been developing significantly well during the last 13 years, but the performance must be improved to be able to gain competitive advantage in the global era. It is crucial for Bank Umum Syariah management to provide excellent service by improving the quality of human employees who are in marital relationship.

Therefore the problem arisen in this research is to analyze how gender relations 
harmony is created by having husband's social support in mediating work and family conflict. It is done in order to improve job satisfaction in supporting Great Malang's Bank Umum Syariah employees' commitment and performance optimally.

Result of this study aims to provide the discourse of ideas for the management of an organization, particularly Bank Umum Syariah based in Great Malang, regarding the significance of implementing human resources quality improvement (especially employee) in the context of family sociology (elimination work-family conflict), and its impact in increasing employee commitment in achieving optimal performance.

From the description of the background research, the problem exhibited this study is formulated as follows: How does the gender roles relation harmony based husband support is capable of ensuring career women's success at Bank Umum Syariah in Great Malang?

Problem of research, among others, are gender and feminism theory. This theory assumes that there is basically no difference between men and women, therefore women should have equal rights with men. Nevertheless, the liberal feminist groups rejected the equation completely or thoroughly of such notion between men and women. There are distinction between men and women, due to women reproductive organs functions which carries logical consequences in life and society.

Role theory. According to the theory, roles in family context could be examined based on model of gender roles. According Talcot Parson, gender role could be divided dichotomonomically into two (2) models, namely: Complete separation of roles between men and women and (Model A), and Consolidation of roles between men and women. Based on Parson nuclear family, it is believed that the feminine role is the expressive role, while the masculine have the instrumental role (Model B). However, in reality, extreme positions or is rarely occur. Instead, compound or mixtures between the two models often occur, which is referring to either of the model or dominant in Model A or B.

Role exchange theory stresses on a person engaging in an interaction possibilities to consider in the context of the off-work exchange. One of its forms is the role exchange within the family, where the husband plays a function or task substituting the wife as she becomes the bread winner. Social behavior is seen as an exchange, a give and take relationship. Homans [2] adds the notion of distributive equation on this theory, for example, the belief that the remuneration should be proportional to a person's sacrifice. As explained by Lambert [3], it links the work-family benefit and organizational behavior, conceptualizing them as intangible "currency" in an exchange between supervisors and subordinates (employees).

The study showed that social exchange theory supports the possibility that the workfamily benefit, workers may feel obliged to perform "extra" for "extra" profit. This theory offers a framework regarding interaction between couple. He also pointed out that social exchange theory could advise in considering reciprocal and multiple simultaneous relationships. It is relevant to the work- family relationship, as work-family dilemma is often related to simultaneous consideration of competitive exchange between work and family.

Family is the smallest unit in society consisting of husband, wife, and child, which includes a husband and a child, or a wife and a child. While the concept of prosperous or harmonious family is a family that is formed based on a valid marriage, is able to meet the spiritual and financial need, devoted to God Almighty, as well as having harmonious relationship between family members and between families in the community. Therefore a prosperous family is a family that meets the following requirements: (1) Mutual marital understanding by performing the duties and obligations according to their roles; (2) The husband appears as good role model for the family in daily life; and (3) A husband, wife and 
children are both materially and morally affluent.

For a husband and wife to implement a harmonious family could be done by managing a prosperous household, ensuring that the family has adequate food and clothing, as well as having a house property. The husband and wife should be understanding of each other and perform their respective duties. The husband earns a living and the wife offers aid wherever possible, as married couple should cooperate in managing their household. A woman who works both at home and outside the home (the public) is known as a career woman.While Islam views the family harmony (Sakinah) is a part of every family ideals of sakinah wawadah warohmah ${ }^{3}$. The concept emphasizes appreciating and practicing religious practice with a grounding faith and devotion to God Almighty, thus forming a good moral (noble) attitudes, actions and behavior.

Muslims interpret wedding as a destination for a family to construct a prosperous household, based in faith towards God Almighty, as well as maintaining family lineage and preventing undesirable aspects. Doing so will require honesty, open-mindedness, and mutual trust between husband and wife in the household. Career women's success is determined by two aspects, first is domestic aspect (family) and the public aspect (work). Therefore, social family support and gender relation harmony, particularly gender role relationship harmony based husband support greatly influence the success of a career woman [4].

\section{RESEARCH METHOD}

Research method employed in this research is qualitative descriptive method is eskriptive of social fenomenon [5]; Prastowo [6]. Research subjects of this research are successful career woman in managerial positions and are capable of maintaining family's harmony (harmonious relationship between husband and wife. Possessing supportive husband, children, and parents should they reside in the same property). This research employs purposive sampling technique. The research key informants on each Bank Syariah are as follows:

TABLE 1 Bank Umum Syariah and Research Key Informant

\begin{tabular}{llll}
\hline No & Bank Umum Syariah & Informant & \multicolumn{1}{c}{ Position } \\
\hline 1 & Bank BRI Syariah Malang & Kristanti, S.H., MM. & Marketing Manager \\
\hline 2 & $\begin{array}{l}\text { Bank Muamalah Syariah } \\
\text { Malang }\end{array}$ & Khairun Nisa, S.E. & Operational Manager \\
\hline 3 & Bank BRI Syariah Batu & Putri Architasari, M Ad. & Operational Supervisor \\
\hline 4 & Bank Muamalah Batu & $\begin{array}{l}\text { Atika Silmi Rahmayanti, } \\
\text { ST }\end{array}$ & Sub Branch Manager \\
& & & \\
\hline 5 & Bank Mega Syariah Malang Titis Widha, SE. & $\begin{array}{l}\text { Head of Operation/ } \\
\text { General Manager }\end{array}$ \\
& & & Supervisor \\
6 & BNI Syariah & Meiry Rachmawati, & KCP Vice-director) \\
& Kepanjen, & S.Ak. & \\
\hline
\end{tabular}




\begin{tabular}{llll}
\hline 7 & $\begin{array}{l}\text { Bank Tabungan } \\
\text { Syariah Malang }\end{array}$ & Diah Budiarti, SPd. & $\begin{array}{l}\text { Logistic/General } \\
\text { Administration(Treasurer) }\end{array}$ \\
\hline 8 & $\begin{array}{l}\text { Bank Mandiri Syariah } \\
\text { Lawang- Malang District }\end{array}$ & Ummul Azizah, S.Ak. & General Manager \\
\hline 9 & $\begin{array}{l}\text { Bank Mandiri } \\
\text { Syariah Malang }\end{array}$ & Ninik L, SE & Branch Manager \\
\hline
\end{tabular}

Source: Processed Primary Data (2018)

Instruments used to collect data in this research are in-depth interviews with the informant themselves and their husbands by utilizing interview guide.

Data analysis in this study uses triangulation qualitative analysis method, which aims to use data triangulation technique and Miles and Huberman [7] qualitative method which includes: (1) data collection involving: data collection and data aggregation obtained by researchers in the field. Sorting process is done afterwards, focusing on data abstraction and transformation obtained in the field, (2) Data analysis involves composed information description, data reduction and presenting the data systematically to allow conclusion to be drawn, (3) Conclusion drawing involves searching through data and information, finding and examine the common ground to serve as the conclusions of the research results.

\section{RESULT AND DISCUSSION}

Gender relations within the career woman's family shows the importance of a woman as a companion to her husband, in which the family will stand strong and prestigious. Should the said woman perform as a wife and homemaker, and father as husband and head of the household, as the main bread winner. The family would be in maintained condition, aligned and in harmony with thebase of mutual understanding, awareness, trust and sacrifice.

The patterns of gender role relationship are related to the division of tasks within the family. When family member possess good relationship to each other, role exchange in career woman's family could run well, and family harmony is ensured to occur. This is supported by the results of Putriani's research [8] which states that a good perception of the gender role relationship occurs when it is viewed as a commitment between husband and wife. "The wife and the husband realized that the gender differences are not to be contested for supporting the family, but it is mutually supportive and complement each other". Therefore in creating a prosperous family, as proposed by Dewayani Soeharto [9], that is a family is said to be in harmony, when every family members are happy, which is characterized by reduced tension, disappointment, and satisfaction with the whole situation and their presence in the family, which cover physical, mental, emotional, and social aspects. Role and status of each family member should be well preserved (each family member perform its primary task, especially husband and wife), support and respect each other as every human being are equal in the eyes of God Almighty.

Gender relation harmony can be achieved in the family, because within such unit one's life as husband and wife began. There are three factors that form harmonious marital relationship: (1) spouse commitment and intimacy (cohesiveness), (2) effective communication, and (3) flexibility in overcoming family problems and finding best solution. Inside a marital relationship, there are needs of the "I" (individual couples) and "us" (couple 
intimacy) should be met in balanced manner. This often requires sacrifice from the "I" of each party supported by values of compassion, trust, responsiveness and empathy as well as a strong self-control.

The results of this study showed that the gender role relation harmony in the family of a career woman requires family support, especially husbands view on work environment, is still tainted by the constraints of social construction and social understanding embraced by the people. Roles that occur in the family are not balanced between husband and wife. As proposed by Widaningsih [ 10 ] are as follows: Families often treat men as "privileged" class and women as second class. Although in certain population groups (middle-class and educated), husband and wife maintain better relationship. When explored further, it appears that in other communities, balanced relationship between men and women is still far from ideal.

The gap in relationships is influenced by historical, cultural, economic and religious aspect that rooted for generations in the community. In fact, it is affecting the lives of women and men in daily activities, both domestically and publicly. Such issue is caused by strong patriarchal culture (culture based on male power). The mentioned patriarchal culture is stereotypes women in marginalized role and position. A new paradigm is needed to provide a framework and explain the relationship between men and woman (husband and wife) in the family units. It will explain how to change gender relations that are gender responsive (ability and sensitivity to observe and assess gender role in various aspects of life, to be capable of realizing gender equality).

Gender relations are generated within a social construction, patriarchal values and customs generating gender inequality, could be seen in the following issues: (1) Different appreciation towards born children, depending on whether the born babies were a boy or girl; (2) In division of labor between husband and wife, husband earn a living outside home (the public sector), while the wife maintain household matters (domestic sector). This division of labor does not generate equal social esteem, because the husband is considered to be the working party and possess economic power, while the wife is often considered as a companion and not as an equal partner; (3) When the wife aids to earn their living in the public sector, the wife's role is expanded outside domestic sector. Despite so, said domestic burdens are not immediately reduced, because the husband does not necessarily participate in the domestic sector, so that the wife's responsibility doubled, which is named multiple role burdens.

Gender equality and gender justice is intended to provide role balance between men and women in family and society, ensuring that there are no roles exclusive to men or women (eg, family economy is charged upon husband as breadwinners, while other roles such as child care, as well as other domestic roles become the wife's permanent role). In ensuring gender equality in forming gender role relation harmony by Yuliati could be considered as follows expert of gender study on Brawijaya University:

"Gender relation harmony could be created by strengthening gender mainstream which aims to reduce gender role gap to ensure that women and men have the same right to selfimprove based on ability and potential. This concept is called "contextual equality". It means that equality is not formula that requires a mathematical equation, but rather equality appropriate to the context of each individual ".

Theoretically, gender relations within the family in the structural- functional theory places the family as an institution possessing a structural system that allocates the position of the husband, wife and children in a vertical position. Role, rights, obligations, and responsibility are determined by patriarchal hierarchy. On the other hand, according to the 
theory of social conflict, this structure has the potential to cause a prolonged conflict, and often creates a non-democratic situations, where the distribution of limited resources (power, opportunity, decisions of the family) are applied by the husband alone, without negotiation process among family members. The conflict will lead to a change in the approach that emphasizes social conflict will raise awareness of individual differences and how to turn these differences into a synergy/harmony in order to create better changes in the family [11].

The result is Dewayani so explained that to construct gender relations in a family, each individual must have mutual understanding on individual differences. They also need to be able to provide appropriate opportunities regardless of gender roles and utilize horizontal companionship approach (non-hierarchical) among family member which allows balanced role division between men and women (especially between husband and wife).

As a career woman, whose role is certainly prone to having a dual role conflict due to the pressure of the two domains, both in work and household sector [12]. Gender roles relations require mutual support between husband and wife in order to create a sakinah mawadah warahmah family [13].

Empirically, based on these thoughts, it is an aspect that should get the attention associated with career woman's social support. Gender relation harmony in the career woman's family would be able to increase their commitment towards Bank Umum Syariah. It would lead towards their success in both managing household and career development [14]. For example: the role between husband and wife in a career woman family could be done in a balanced way that does not forget a woman characteristic as wife and mother as well as a good citizen.

Patriarchal culture is analyzed in this research to give a perspective on the roles of men and women in the family. Khanifah [15] explained that traditionally it is the role of men to act as a breadwinner (public sector) and women's role managing the household (the domestic sector). But as society develops, it requires social changes where role exchange is done women active in the public sector. Such phenomenon of career woman is a part of the progress for women to reach equal position and partnership, therefore developing gender role relation harmony [16].

There are three types of gender role relation harmony based husband support. There are three categories exhibiting career women's aspiration. Interviews with key informants in defining the success of career woman and how your future career aspirations in general can be classified into three (3) which are exhibited in the table below:

TABLE. 2 Carrier Aspiration Classification

\begin{tabular}{|c|c|c|}
\hline $\begin{array}{l}\text { Cate- } \\
\text { gory }\end{array}$ & Career Woman Aspiration & Reasoning of Husband \\
\hline 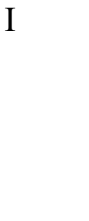 & $\begin{array}{l}\text { Obtaining husband's full support. } \\
\text { Capability in dividing the time required } \\
\text { for office hour and family. Islamic work } \\
\text { atmosphere and able to bringing child } \\
\text { on overtime }\end{array}$ & $\begin{array}{l}\text { Proud of wife's successful career. } \\
\text { Maintain good trust and communication. } \\
\text { Aiding family's economy. } \\
\text { Support each other's carrier (Husband } \\
\text { works at BNI Syariah Kepanjen). }\end{array}$ \\
\hline
\end{tabular}
wife cooperation. Household matters are done by household assistant. 


Obtaining high prestige.
Obtaining pride. Supportive husband.
Professionalism in career. Aiding family
economy.
Maintaining Islamic Syariah in career.

Maintaining trust and communication
with husband.
Maintaining time for office hour and
family.
Islamic work atmosphere. Supporting
family economy. Improving career
while maintaining balance with
household matter and family
relationship.

III Being too focused at work and having no time to look after the children. Focus in looking after the children. Dissatisfaction in work, if it sdisturbs allocated time for family. Communicate with husband to reach understanding. Will resign after giving birth and focus in looking after children. Work is a form of prayer.

When given a choice between family and work, will focus on family.

\begin{abstract}
Wife's master degree should be implemented in her career.

Being understanding of each other. Utilizing household assistant service. Career success doesn't necessarily means success in maintaining family.
\end{abstract}

Allowed to work in Islamic based offices.

Allowed to work for self improvement. Supporting family economy.

Balancing office hour and family time. Supports wife's creativity and implementing her knowledge. Respecting wife's ability and desire.

Children need their mother.

Should focus on family. Adequate family economy.

Does not fully allow a wife to work, but acknowledges she has the right. Both are focused on work therefore lacking time to be allocated for family. Supports wife's decision to resign and focus on the family.

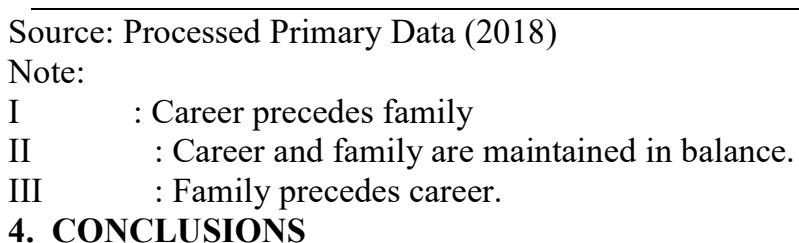

Based on analysis done in this research, it could be concluded that a husband's support greatly affect the decrease in dual role conflict (work-family conflict). It is necessary to obtain a solution by offering adequate reward to offset working hour. By doing so, it will create a significant impact on job satisfaction, particularly on issue related to salary received and work performance. A career woman's success is supported by the following aspects: (1) Capability in providing family income economically and does not necessarily depend on her husband, (2) Capability in implementing possessed knowledge and obtaining "status" for the sake of self-improvement.

Gender relation harmony based husband's support exhibits that there are three categories of a career woman's significance: (1) career takes precedence over family, (2) career and family are considered equally important, and (3) the family takes precedence over career. If, when a career woman are in marital relationship and possesses children, it is advised to employ "aid" as household assistant in order to maintain household matter. Baby sitter 
and similar institutions play roles could have taken over the domestic role of a mother. Day care or lactation / nursing mothers' room could be provided in the work environment as an attempt to minimize dual role conflict. By doing so, career women are able to devote their energy and resources for organization improvement.

Gender relation harmony should be maintained. Making decisions in determining the course of a career or career discontinuation should be done thoughtfully, because it concerns the future of the family economy and implementing possessed knowledge of highly educated women as a form of self improvement.

\section{REFERENCES}

[1] Asriani, Desintha, Dwi, 2013, Wacana Asi Eksklusif, Dilema Peran dan Konstruksi "Ibu yang Baik", Jurnal Perempuan: Karier dan Rumah Tangga, Vol 8, No 1, Maret 2013, hal 43-63, ISSN: 1410-153X

[3] Lambert, Susan.J.1990. Processes Linking Work and Family: A Critical Review and Research Agenda. Human Relations, 43(3), 239-257.

[4] Utaminingsih, Alifiulahtin, 2008, Analisis Gender tentang Stres Kerja, Kepuasan Kerja dan Komitmen pada Organisasi, Jurnal Telaah Bisnis, Volume 9, No. 2 Deaember 2008, ISSN 1411-6375, Yogyakarta

[5] Moleong, Lexy, J., 2006, Metodologi Penelitian Kualitatif, Remaja Rodsdakarya, Bandung

[6] Prastowo, Andi, 2012, Metode Penelitian Kualitatif, Ar-Ruzz Media, Yogyakarta

[7] Miles, Matthew, B. dan A.Michael, Huberman, 2014, Analisis Data Kualitatif, UI Press, Jakarta

[8] Putriani, Grace, Flora, 2007, Kesuksesan Peran Ganda Wanita Karier ditinjau dari Dukungan Suami, Optimisme dan Strategi Coping, Laporan Studi SKW, Yogyakarta

[9] Dewayani Soeharto, T.N.E., 2013, Konflik Pekerjaan-Keluarga Pada Ibu yang Bekerja, Ditinjau dari Dukungan Suami, Jurnal Sosio Humaniora, Vol. 4, No. 5, Mei 2013, page: 2939. ISSN:2087-1899

[10] Widaningsih, 2015, Paper: Relasi Gender dalam Keluarga: Internalisasi Nilai-Nilai Kesetaraan dalam Memperkuat Fungsi Keluarga, Tim Pokja Gender Bidang Pendidikan Dinas Pendidikan Provinsi Jawa Barat.

[11] Utaminingsih, Alifiulahtin, 2017, Gender dan Wanita Karir, UB Press, Malang

[12] Widayani dan Hartati, 2015, Kesetaraan dan KeadilanGender dalam Pandangan Perempuan Bali: Studi Fenomenologis terhadap Penulis Perempuan Bali, Jurnal Psikologi UNDIP, Volume 13, No 2, Oktober 2014: 149-162.

[13] Puspitawati, Herien, 2013, Fungsi Keluarga, Pembagian Peran dan Kemitraan Gender dalam Keluarga, IPB Press, Bogor

[14] Churiyah, Madziatul,2011, Pengaruh Konflik Peran, Kelelahan Emosional terhadap Kepuasan Kerja dan Komitmen Organisasi, Jurnal Ekonomi Bisnis, Tahun 16, No. 2, Universitas Diponegara, Semarang, Jawa Tengah

[15] Khanifah, 2013, Perempuan yang (Di) Kalah (kan), Jurnal Perempuan, April, 2012, ISSN:1410-153X, hal: 60

[16] Mufidah, 2009, Pengarusutamaan Gender pada Basis Keagamaan: Pendekatan Islam, Strukturasi \& Konstruksi Sosial, UIN-Malang Press 